\title{
Impression management in the letters to shareholders of listed entities: A R omanian case study
}

\author{
Maria-Silvia Săndulescu ${ }^{\mathrm{a}, 1}$ and Cătălin-Nicolae Albu ${ }^{\mathrm{a}}$ \\ a The Bucharest University of Economic Studies, Romania
}

\begin{abstract}
A bstract: There is recent increased interest in investigating the way corporate reports are used to convey management's view of organizational performance. While previous research was mainly conducted in developed economies, the case of emerging economies in Southeast Europe provides new insights as these countries are characterized by poorer corporate governance mechanisms, a lack of transparency and higher ownership concentration. We fill this gap in literature by investigating the letters to shareholders issued by OMV Petrom, the largest oil and gas producer in Southeast Europe. Using content analysis, weeval uate the tone used by managers in their disclosures in order to identify any reporting biases via impression management techniques. Even though OMV Petrom is perceived in literature as a benchmark for reporting transparency, our results provideevidence of promotional aspects used in corporate narratives.
\end{abstract}

Keywords: impression management; content analysis; financial performance; tone; corporate narratives; emerging economies.

JEL codes: D82, M41

\footnotetext{
${ }^{1}$ Corresponding author: Department of Accounting and Auditing, The Bucharest University of Economic Studies, Piața Romană no. 6-8, sector 1, București, Romania. Tel: +4021 31919 00; email: maria.sandulescu@cig.asero
} 


\section{Introduction}

In this paper we analyse the letters to shareholders issued by OMV Petrom, a Romanian entity listed on the Bucharest Stock Exchange (ro. Bursa de Valori Bucureşti-BVB), to detect any reporting biases via impression management (IM) techniques. IM has recently become a favourite research topic, as literature shows that the purpose of corporatenarratives is not al ways to increase the transparency by reducing the information asymmetry between the managers and actual and potential investors (Clatworthy \& Jones, 2006; Merkl-Davies \& Brennan, 2007; Rutherford, 2005). While most I M research has been conducted in western devel oped settings, little is known about such behaviours potentially affecting organizational reporting in emerging economies, particularly geographically located in Southeast Europe (SEE).

OMV Petrom is the largest Romanian company and the largest oil and gas producer in SEE. The company is part of theOMV Group, and its main sharehol ders (as stated on the company's website as of 31 December 2017) are OMV Aktiengesel lschaft (holding $51 \%$ of the shares), the Romanian State through the Ministry of Energy (20.6\% of the shares), Fondul Proprietatea (9.9\% of the shares), and the rest being held by other shareholders. In 2004 the former Romanian company Petrom was subject to a contested privatization (Lupu \& Sandu, 2017). The company was profitable until 2015, when it incurred its first time ever loss. This short period is characterized by a deep contrast, as OMV Petromobtai ned in 2013 the highest profit ever recorded in Romania (Musgociu, 2014). Consequently, we are looking at the letters to shareholders issued by OMV Petrom between 2012 and 2015, which gives us an opportunity to reflect potential IM practices and identify any differences that may arise between profit and loss periods.

The increasing interest in understanding the communication process between companies and its stakeholders has heightened the need for analysing the IM strategies used by managers to favourably portray the investment image (Brennan \& Merkl-Davies, 2013). From an economic perspective, rooted in the agency theory, IM may arise when managers (as rational decision makers) take advantage of the information asymmetry that exists between them and the shareholders (who are subject to bounded rationality) (Krische, 2005; Merkl-Davies \& Brennan, 2011; Schrand \& Walther, 2000). The managers' inherent motivation is the maximization of their own wealth (Merkl-Davies \& Brennan, 2011; Y ekini etal., 2016). Therefore, as negative organizational outcomes may generate conflicts of interest between the principal and the agent, "management has economic incentives to disclose messages that convey good performance more clearly than those conveying bad performance" (Rutherford, 2003: 189). This reporting bias concerning the companies' financial performance will further result in short-term capital misallocations (Merkl-Davies \& Brennan, 2007). Also, IM strategies may be as subtle as to be imperceptible (Henry, 2008), hence one must be careful as they may contradict the faithful 
representation of information (Beattie \& J ones, 2000; Clatworthy \& J ones, 2003, 2006; Guillamón-Saorín \& Martínez-López, 2013).

Even if narratives may be partly used to build brands and manage impressions, some research supports the incremental value of the information disseminated by companies (Baginski et al., 2000; Dainelli et al., 2013; Y ekini et al., 2016; Y uthas et al., 2002) by underlining the contribution of narratives to the reduction of informational asymmetries (Y ekini et al., 2016). In addition, it is considered that companies' reputation (Yekini et al., 2016), share price and cost of capital (MerklDavies \& Brennan, 2011) can be negatively impacted as a result of a possible identification of biased disclosures by users (Rutherford, 2005; Y ekini et al., 2016; Y uthas etal., 2002). Evidenceis thereforemixed in terms of the context and outcome of potential management attempts to manage impressions as reflected in company reports.

Although considerable research has been devoted to the study of IM in the context of developed economies such as the United States of America (eg. Alle \& DeAngel is, 2015; Henry, 2008; Priceetal., 2012; Y uthas et al., 2002) and theUnited Kingdom (e.g. Clatworthy \& J ones, 2003, 2006; Rutherford, 2005; Y ekini et al., 2016), less attention has been paid to emerging economies. Understanding whether and how these strategies may be used by entities located in the SEE countries may be extremely fruitful since they are in the pursuit of economic development, experiencing higher growth rates and profitability. It is thus a contribution of this paper that we are evaluating the way and the extent to which IM may differ in the context of emerging countries of SEE. While transparency is highly neglected by companies in the Central and Eastern European (CEE) region (Gîrbină et al., 2012), OMV Petrom is perceived as being „a model of good practices” (Albu et al., 2014b: 337). However, Cho et al. (2012: 35) highlight that in these conditions, users of accounting information may "fail to real ize the inherent biases in the reporting, and continue to laud the practice as evidence of increased corporate transparency and accountability". We are thus mobilizing the case of OMV Petrom as an example of how corporate reporting may be influenced by management in an under-researched context, via the case study of a very large, internationally-owned entity, acting in a sensitive domain (oil and gas) and with of great national and regional importance.

From a methodological standpoint, we eval uate the tone used by management in corporatenarratives in order to identify any potential reporting biases. In this respect, weidentify positiveand negative words as suggested in the Loughran and McDonald (2011) dictionary and Henry's (2008) wordlist in OMV's letters to shareholders issued between 2012 and 2015. Examples of such words are "efficiency", "favourable", "great", „successfully", „enhance”; examples of negative words are "decline", "failed" or "losses". Because 2015 was the first year when the company recorded a loss, it is probable that opportunistic practices may be identified (Clatworthy \& Jones, 2003; Merkl-Davies \& Brennan, 2011; Rutherford, 2005). Overall, we find a decreasing number of both positive and negative words used in 
the letters to sharehol ders from 2012 to 2015 , correlated with a similar decrease in the lengths of the letters. Following previous research (e.g., Merkl-Davies \& Brennan, 2011) we had anticipated a different number of words used in 2013 as compared to 2015. However, contrary to prior literature, our results also highlight a steep decrease in the number of both positive and negative words between 2012 and 2013 (40\% decrease). This finding is surprising since 2013 was the year when the company recorded the highest profit after privatization, and there was no apparent reason to mislead the users of accounting information.

Our results al so provide evidence consistent with the Pollyanna effect (Henry, 2008; Rutherford, 2005). Particularly, we identify a tendency to present the company's outcomes in a positive light, both in profit and loss periods. A lack of objectivity is therefore reflected in the use of positive rel ative to the use of negative keywords.

We contribute to literature in several ways. First, as foreshadowed before, we provide evidence of manipulating behaviour from an emerging economy, and the largest oil and gas company in SEE. We thus contribute to a nascent literature (e.g. Hadro et al., 2017) on IM behaviour in an under-researched region of the European Union (i.e. Central and Southeast Europe), which is quite significant in size and raised increased economic interest Second, we use a case study approach (Y in, 2014), a research method that all ows for in-depth understanding of the issues under consideration. We are thus able to explore the context of a company that is representative of the reporting practices in SEE. The results of our research should therefore be useful for researchers interested in the effect of the implementation of Western-inspiration reforms in SEE; for accounting professionals and management, who should be interested in how companies' reports are looked at by users of financial information; for investors, to understand the context of rapid growth of the SEE countries; and for regulators of financial reporting and stock exchanges, who should seek evidence about the organizational financial reporting practices and how these can shape and induce unwanted investor behaviour.

The remainder of this paper is organized as follows. A review of the relevant literature is presented in section 1 , while the research background is described in section 2. Section 3 sets out the methodology we applied for the purpose of this study. Results are presented in section 4. The paper concludes with a discussion of the contributions, implications and future research directions.

\section{Literature review}

IM has recently become a favourite research topic, as literature shows that the purpose of corporate narratives is not always to increase the transparency by reducing the information asymmetry between the managers and actual and potential investors (Clatworthy \& Jones, 2006; Merkl-Davies \& Brennan, 2007; Rutherford, 2005). Froman economic perspective this opportunistic behaviour may betheresult of the managers' intentions to maximize their remuneration (Merkl-Davies \& 
Brennan, 2011; Y ekini et al., 2016) by taking advantage on the limited rational ity of the shareholders (Krische, 2005; Merkl-Davies \& Brennan, 2011; Schrand \& Walther, 2000). Consequently, the narrative segments of the annual reports may be used to favourably portray the financial performance of the company (Clatworthy \& J ones, 2001, 2006; Riley \& Luippold, 2015). This reporting bias entitles thetendency to conceal negative information and enhance positive results (Beattie \& J ones, 2000; Brennan et al., 2009; Merkl-Davies \& Brennan, 2007, 2011). As Clatworthy and J ones (2001: 311) argued, "management may well seek to manage their narratives just as they manage other features of the annual report such as earnings".

Adverse effects, such as short termcapital misal locations (Brennan \& Merkl-Davies, 2013; García Osma \& Guillamón-Saorín, 2011; Leung et al., 2015; Merkl-Davies \& Brennan, 2007) may arise especial ly because the annual reports are widely used in the decision making process (Clatworthy \& Jones, 2003; Breton \& Taffler, 2001 cited by Davison, 2008). In other words, „both lay and expert readers are open to persuasive devices and unconscious signals" (Davison, 2008: 794). As a result, knowing the IM strategies is the first step that has to be taken on the way toward understanding and interpreting the inherent purposes of the information discl osed by companies (Rutherford, 2005). Although the efficiency of these practices cannot be generalized (Rutherford, 2005), „any investor can neglect relevant aspects of information, without fully real izing that their attention is imperfect" (Hirshleifer \& Teoh, 2003 cited by Krische, 2005: 265).

Previous studies (Henry, 2008; Rutherford, 2005) have argued that the tone used by companies in their disclosures may influence the users of accounting information. This IM strategy is general ly referred to in the literature as thematic manipulation (eg. Brennan et al., 2009; García Osma \& Guillamón-Saorín, 2011; GuillamónSaorín \& Martínez-López, 2013; Merkl-Davies \& Brennan, 2007). As Yekini et al. $(2016,418)$ notes,

influence is conceptual ized as a cumulative series of signals in the text that, when read by the actor, gradual ly brings about cognitive structure change and a change in attitude (...) the more often positive tone expressions arementioned in the text, the more likely it is that they will be influential.

Moreover, a lack of objectivity has been noticed in the use and abuse of positive words (Clatworthy \& Jones, 2003, 2006; Guillamón-Saorín \& Martínez-López, 2013; Rutherford, 2005) known as the Pollyanna principle (Mattin \& Stang, 1978 cited by Rutherford, 2005). However, according to Rutherford (2005: 375), IM may reach its efficiency by using "a level of positive charging that users might not be expecting and thus might not allow for appropriately". 
So far, IM research was mainly conducted in developed economies and it is currently still unclear whether differences may appear in emerging countries. A research background such as SEE offers several opportunities for in depth analysis since this area is characterized by poor corporate governance mechanisms (Berglöf \& Paj uste, 2005), a lack of transparency, ownership concentration and less demanding users of information (Albu \& Gîrbină, 2015). Significant amount of changemanifested in the SEE countries after the fall of communism in the region in the late 1980s - early 1990 s (Zecchini, 2013). The countries were left without any equity markets and with weak banking sectors (Mueller \& Peev, 2007) and high levels of perceivecorruption and discontent with government efficiency (Djankov et al., 2016). However, significant pressure from international funding institutions such as the International Monetary Fund (IMF) or the World Bank (WB) has prompted sustained actions to reform the countries' political, economic and social institutions and practices. Currently, such countries enjoy one of the fastest economic growth in the European Union, have modernized their written laws and regulations, and have improved the functioning of their markets (World Economic Forum, 2016). In this context, it would be interesting to investigate the potential opportunistic management behaviour apparent in the companies' reports on the way to attracting investors or consolidate management's perception.

The IM literature in emerging economies is scarce at best. One notable exception is Hadro et al. (2017), looking at the IM practices of Polish listed firms. By using content anal ysis, the authors find patterns of IM techniques used by management of Polish listed firms. Results underline the importance of ownership concentration, where companies with more concentrated ownership tend to write shorter letters, particularly where there are many insiders holding shares.

We thus contribute to this literature by seeking to answer the following research question: Are corporate narratives informative or do they play a promotional role? While a promotional role will be reflected in a tendency to maintain a positive tone both in periods of profit and loss, an informational purpose will involvean objective perspective (Henry, 2008; Rutherford, 2005).

\section{Research background}

\subsection{Romania as an emerging economy}

In this study we provide evidence from Romania, a country in the pursuit of economic development, after a prolonged exposure to the negative effects of a communist ideology (Albu et al., 2014a; Deaconu \& Cuzdriorean, 2016). Although the economy is under the influence of European Union (EU) Directives and International Financial Reporting Standards (IFRS) (Albu \& Albu, 2017) due to the EU membership, (reporting) deficiencies (and not only) still prevail. The stock 
market is still characterized by a low level of liquidity (Albu et al., 2014a), while corporate governance princi ples are not properly enforced (Albu \& Gîrbină, 2015). Romania has a population of al most 20 million inhabitants, making it the largest SEE member of the EU (WB, 2016a). After thefall of communismin 1989, the Romanian economic setting underwent a major reform process which involved the changefrom a social ist to a capital ist economy (Dobre, 2010; Piątek et al., 2013). In this respect, a significant impact had the application for EU membership in 1993 (Albu \& Albu, 2012; Ionașcu et al., 2014). Moreover, theWB and I MF requested several conditions to be met in order to grant the loan that could further support the economic devel opment of the country. The subsequent results were reflected in an increase in GDP from US $\$ 37.4$ billion (in 2000) to US\$208.2 billion (in 2008) (WB, 2016b). Although the crisis caused a recession of around $7 \%$, positive val ues wereonceagain recorded in 2011, the current level being 4.8\% (Eurostat, 2016a). This positive view is further confirmed by the declining trend of unemployment and inflation rates (Eurostat 2016b, 2017).

In a codelaw country, International Accounting Standards/IFRS implementation was therefore the result of the conditions imposed by the WB, being perceived as a useful tool to influence the perception of foreign investors (Albu \& Albu, 2012). Framing a positive image was necessary in a local environment where accounting is highly influenced by taxation requi rements (Al bu et al., 2011). This situation resides in the dominant position exerted by Romania's accounting regulator, namely the Ministry of Public Finances (Albu et al., 2014a). The process of implementation began in 2001 but after 2007, when Romania became an EU member, IFRS became mandatory only for consol idated listed companies and credit institutions. Although previous literature (e.g. Albu \& Albu, 2017) document a good level of convergence between IFRS and the local regulations, "one cannot say that IFRS are fully understood and implemented by the Romani an companies even today, since merely imposing some standards is not enough to have them applied" (Albu et al., 2011: 94). Even though the inherent benefits of IFRS are acknowledged by local users of accounting information, practitioners are still influenced by the ,routines established in the preIFRS period"' (Feleagă \& Feleagă, 2016: 402).

A nother condition of the WB concerned the development of the financial market (Albu \& Albu, 2012). Established in 1995, theBVB still has a low level of liquidity. As stated on the BVB' website, only 86 companies are currently listed on the main regulated market and have a significant percentage of foreign or institutional investors (such as pension or investment funds). In 2001 BVB issued the first Corporate Governance Code that was further replaced by a new one in 2008. Although the formal requirements exist, the inefficient enforcement generates a low level of transparency (Albu \& Gîrbină, 2015; Feleagă et al., 2011). Moreover, prior literature documents the Romanian companies' tendency to ,indicate compliance where it is not the case in practice" (Albu \& Gîrbină, 2015: 102). 


\subsection{OM V-Petrom as the case firm}

OMV Petrom holds a leading position in the oil and gas industry in Romania and the SEE region. The privatization of the company was part of Romania's transition from a centralized towards a market economy. The practice of Initial Public Offering (IPO) that was adopted by the CEE countries (Păun et al., 2010) was al so used in the case of Petrom Although the privatization process began in 1995, the IPO prospectus was released in 2001, while the contract between the Romanian Government and the Austrian group OMV was signed in 2004 the. Since then, the contract became the main source of dispute, its conditions being highly contested by both politicians and the media. To this point, Lupu and Sandu (2017: 542) outline not only the "unfortunate and unfavourable conditions for Romania but al so on the negative consequences of its high and unj ustified price hikes and creation of national dependency with regards to the security of the country's energy supply". The contract was al so scrutinized in the 2014 report of the Romanian Court of Accounts (Romanian Court of Accounts). According to this report, the buyer (OMV), failed to respect the Decision issued in 2009 to increase the share capital by considering the revalued amount of the lands at the moment when the privatization contract was signed. Nonetheless, OMV benefited from the write off of several existing liabilities of Petrom's, and small royalties that the company has to pay for the Romanian natural resources (Dimitriu, 2006).

Petrom was listed for the first time on BVB in 2001 and, on the London Stock Exchange in 2016, following the secondary public offering. Petrom's free float increased from 6.62\% in November 2012 to $18.3521 \%$ in September 2017, being the largest company listed on the BVB. Despite this fact, „a successful privatization from a financial and economic point of view does not automatical ly equate to social acceptability and legitimacy" (Lupu \& Sandu, 2017: 560).

On the other hand, OMV Petrom is perceived in literature as a benchmark for reporting transparency (Albu et al., 2014b; Albu et al., 2011). However, Cho et al . (2012: 35) argue that in these conditions users of accounting information may "fail to realize the inherent biases in the reporting, and continue to laud the practice as evidence of increased corporatetransparency and accountability". OMV Petromthus makes a very useful and instrumental case company, one able to shed light on the reporting practices of a large entity that was transformed from a not-so-profitable state-owned institution into a very successful major player on the international oil and gas market

\section{Research methodology}

This study was designed to evaluate the tone used by managers in their letters to shareholders. In this respect, the suitability of a case study is reflected in the 
"opportunity to study the changes in disclosure by one company without possible contamination through the integration of different corporate values, strategies and personnel" (Tilling \& Tilt, 2010: 66). Accordingly, we have gathered the corporate annual reports issued by OMV Petrom between 2012 and 2015 ( 4 reports) from the company's website. We considered the English version of the annual reports (and thereforetheletters to shareholders) in order to ensurereproduci bility (Krippendorff, 2004) and facilitate comparison with prior literature

The period was chosen with the view of identifying potential contrasts in the reporting behaviour between high profit and loss years. While OMV Petrom's financial performance has increased during the first two years included in our anal yses, the company was very negatively affected by theoil crises in the following ones. Over this period, the oil barrel price hit $\$ 49.87$ (in March 2015), only to become even lower (\$29.67 in J anuary 2016), 10-year lowest price (Macrotrends, 2018). The period under consideration is however characterized by consistency regarding the company's Chief Executive Officer (CEO), Chief Financial Officer and auditor (Emst \& Y oung). Moreover, 2012 was the first year following privatization when the members of the supervisory board were not changed. At that time the board had 9 members, and Gerhard Roiss was the president of the Board of Directors of OMV Petrom as well as OMV's CEO. He had been a member of the board since 2004 when the company was privatized and became the new president since A pril 2011. He was replaced in 2015 by Rainer Seele as a result of the poor financial results incurred by OMV and OMV Petrom (Petrescu, 2014). OMV Petrom's CEO between 2006 and 2018 was Mariana Gheorghe. She was a member of the new board of directors that was appointed in 2004, when the privatization contract was signed. Starting with 2006 she has been the company's CEO and is one of the most powerful businesswoman in the world (Fortune, 2012-2014). In 2010 Mariana Gheorghe received 100 shares that were distributed free of charge, while her husband owns 60,000 shares.

Table 1 gives an overview of the characteristics of the letters to shareholders investigated (no. of pages, no. of paragraphs, no. of words) As noted from Table 1, the total length of the letter to shareholders (measured as the number of words) has significantly decreased from 2,048 words in 2012 to 1,239 in 2013 (40\% decrease) and maintained a declining trend until 2015.

Table 1. Characteristics of the letters to shareholders analysed

\begin{tabular}{llllll}
\hline & 2012 & & 2013 & 2014 & 2015 \\
\hline Pages & 4 & 2 & 2 & 2 \\
Paragraphs & 19 & 11 & 17 & 11 \\
Words & 2048 & 1239 & 1233 & 1052 \\
\hline
\end{tabular}


In line with prior literature (Melloni, 2015; Melloni et al., 2015), manual content analysis was performed to evaluate the disclosure tone by analysing the language used in reporting. A classification of positive and negative keywords was done by using Loughran and McDonald (2011) dictionary available on the authors' website. It includes 354 positive words and 2,329 negative words that were identified by examining language in a large sample of $10-\mathrm{K}$ fillings $(50,115$ observations consisting of 8,341 unique firms) submitted to the Securities and Exchange Commission. Examples of positive words are "efficiency", "favourable", "great", "successfully", „enhance”; examples of negative words are „decline”, „failed" and "losses". This dictionary was used in accounting and financeliteraturefor measuring the tone of the business communication (Allee \& DeAngelis, 2015; Davis et al., 2015; Feldman et al., 2010).

Moreover, we used the positive and negative wordlists developed by Henry (2008) for analysing financial text This wordlist includes 105 positive and 85 negative keywords, being the first one developed in the literature for financial text analysis (Loughran \& McDonald, 2016). Although the number of words is smaller relativeto the Loughran and McDonald (2011) dictionary, the Henry (2008) list includes 46 positive and 35 negative words that are not dlassified as positive or negative by Loughran and McDonald (2011). Examples of positive unique words are: "certain", „increase”, ,rise”, „more”, ,record”; examples of negative unique words are: „risk”, "down", "decrease", ,drop". Its specificity and utility was demonstrated in previous studies that measured tone in earnings conference calls (Davis et al., 2015; Price et al., 2012).

In order to overcome the limitations of a computer-aided analysis, we identified the keywords in context (Krippendorff, 2004). We did not count the positive word "growth" when it was used to mention the percentage of "economic growth", or the word "up" when it was part of a phrasal verb. Weal so adjusted for negation and we eliminated negative words such as "Iost", „injury", "unemployment", "fatalities" when they were followed by the word "rate". At this stage, a total number of 18 words were excluded. Finally, we investigated directional keywords such as "decreased", ",increased", "higher" or "lower", because they can be affected by ambi guity (Henry, 2008). Disambiguation entails „distinguishing the positiveversus negative context-dependent affect of the specific words" (Henry, 2008, 399). Therefore, analysing these words in context gave us the possibility to determine whether they were used in a positive or negative sense. Following Clatworthy and Jones (2003), the assessment was done from a shareholder perspective and as a result, 14 negative and 5 positive keywords were eliminated in the process of disambiguation.

We have further computed a tone measure by using the Henry (2008) formula: positive words less negative words over the sum of positive and negative words. Therefore, the tone measure is a continuous variable that takes val ues betwen -1 and 1; the closer this measure is to 1, the more positive is the tone used in the 
document analysed. In this respect, previous studies that have used this formula in assessing tone reported mean values of 0.568 (Henry, 2008), and 0.64 (Price et al., 2012). Following previous literature, we expect the accounting narratives to be biased toward the positive especially in the two years (2014 and 2015) when the financial performance of the company started to decrease (Clatworthy $\&$ Jones, 2003; Merkl-Davies \& Brennan, 2011; Rutherford, 2005).

\section{Results and discussions}

We identified a total number of 78 positive and 45 negative keywords in the sample period, using the wordlists devel oped by Loughran and McDonald (2011) and Henry (2008) (see Table 2). We found 48\% of the positive words from Henry's (2008) list in the reports we used. Although Henry's (2008) wordlist comprises 105 positive words, compared to Loughran and McDonald (2011) dictionary of 354 positive words, the former has an increased specificity and applicability than the latter. However, the length of the Loughran and McDonald (2011) dictionary proved its useful ness in the anal ysis of negative keywords. In this respect, 27 unique keywords were identified and this offered the opportunity to analyse in depth the frequency of their occurrences.

Table 2. Number of positive and negative keywords identified

\begin{tabular}{llllll}
\hline & Total & $\begin{array}{c}\text { Loughran \& } \\
\text { M CDonald (2011) }\end{array}$ & Henry (2008) & Both \\
\hline Positive & 78 & 28 & 25 & 25 \\
Negative & 45 & 27 & 12 & 6 \\
\hline
\end{tabular}

Table 3 illustrates the frequency of positive and negative keywords identified in the sample period. An overall decrease year on year may be observed, evolution consistent with the decreasing number of total words used in the company's narratives over the same period. Following previous research (e.g. Merkl-Davies \& Brennan, 2011), we anticipated a different number of words used in 2013 as compared to 2015. Even if our results confirm our expectation (a 15\% decrease in the number of words used), we al so note an even bigger decrease between 2012 and 2013 (i.e. 40\%). This finding is surprising since 2013 was the year when the company recorded its highest profit after privatization, and there was no apparent reason to mislead the users of accounting information.

Table 3. Frequency of positive and negative keywords

\begin{tabular}{lllll}
\hline & $\mathbf{2 0 1 2}$ & $\mathbf{2 0 1 3}$ & $\mathbf{2 0 1 4}$ & $\mathbf{2 0 1 5}$ \\
\hline Positive & 97 & 73 & 69 & 60 \\
Negative & 31 & 20 & 22 & 18 \\
Length & 2048 & 1239 & 1233 & 1052 \\
\hline
\end{tabular}

Note: Length is expressed as the number of words in the letters to shareholders. 
We now tum to the examination of the tone and the company's financial performance indicators. Table 4 highlights the fact that the tone was maintained positive across the entire period of analysis, with almost constant and increased values that are comparable with previous findings in the literature (Henry, 2008; Price et al., 2012). In 2013 both EBIT and profit increased with $5.2 \%$ and $22.2 \%$ respectively, while the tone measure had a similar evolution (10.5\% increase). However, in 2014, when these two performance indicators decreased by al most $50 \%$, the tone measure was reduced only to a si milar but still higher value than the one in 2012. These results are further emphasized in 2015, when although the company recorded a loss, the tone measure actually increased reflecting Pollyannaish tendencies (Henry, 2008; Rutherford, 2005).

Table 4. Analysis of the tone used in the letter to shareholders and key performance indicators

\begin{tabular}{lllll}
\hline & $\mathbf{2 0 1 2}$ & $\mathbf{2 0 1 3}$ & $\mathbf{2 0 1 4}$ & $\mathbf{2 0 1 5}$ \\
\hline Tone & 0.5156 & 0.5699 & 0.5165 & 0.54 \\
EBIT & $5,662.00$ & $5,957.86$ & $3,338.30$ & -529.75 \\
Profit & $3,946.10$ & $4,824.04$ & $2,099.67$ & -689.65 \\
\hline
\end{tabular}

Notes: Tone is measured as a continuous variable taking val ues between -1 and 1 , calculated as positive words less negative words over the sum of positive and negative words. EBIT and Profit figures are expressed in million RON. 1 EUR=4.6 RON (as of 24 October 2017).

The following quote shows how OMV Petrom's CEO presents the financial performance of the company in direct contrast with the conditions provided by the economic environment in which the company operates. The emphasis of the positive results is not surprising since in $2013 \mathrm{EBIT}$ and profits increased by $5 \%$ and $22 \%$ respectively compared to 2012 . The same ascending trend can be observed for the tone measure.

In 2013, Petromperformed very well and delivered strong financial and operating results, in spite of persistent macroeconomic challenges in our area of operations (OMV Petrom, 2013) (emphases added).

It can be noticed how the positive keywords were linked with the image of the company, while the negative word "challenges" was used to describe the environment This observation determined us to compare and contrast thenarratives from 2013 and 2015 in order to analyse the way in which language is used in rel ation to the company or the environment. Table 5 provides an illustration of the most frequently used keywords in this period. We can easily remark the similarities between the two lists and the fact that only positive words are included in this ranking. Although the frequency of positive keywords slightly decreased in 2015, 
the choice of words is inappropriate in this period of sharp contrast between the highest profit ever recorded and the first loss after the privatization.

Table 5. Comparative analysis of the keywords used to describe the company in profit vs. loss years

\begin{tabular}{lccccccc}
\hline 2013 (profit) & Frequency & Company & & 2015 (loss) & Frequency & Company \\
\cline { 1 - 3 } \cline { 5 - 7 } Growth & 7 & 6 & & Higher & 6 & 3 \\
Increased & 4 & 4 & & Deliver & 3 & 3 \\
Strong & 4 & 4 & & Delivered & 3 & 3 \\
Achieve & 3 & 3 & & Efficiency & 3 & 3 \\
Delivered & 3 & 3 & & Improved & 3 & 3 \\
Efficiency & 3 & 3 & & Strong & 3 & 3 \\
High & 3 & 3 & & Growth & 3 & 2 \\
More & 3 & 3 & & Achieved & 2 & 2 \\
Progress & 3 & 3 & & More & 2 & 2 \\
Achieved & 3 & 2 & & Successfully & 2 & 2 \\
\hline
\end{tabular}

In addition, Table 6 confirms the aforementioned observation, as around $80-89 \%$ of the positive words are attributed to the company. This result is in direct contrast with the overall performance in 2015, when the financial results were negative. Consequently, we can confirm previous research that supports Pollyannaish effects (Henry, 2008; Rutherford, 2005). As shown in our case, the tone measure increased from 2014 to 2015 although the financial performance of the company decreased drastically; this positive tone is mainly used to favourably portray the company.

Table 6. Attribution of positive and negative keywords

\begin{tabular}{lcccccc}
\hline Panel A. 2013 & Total & \multicolumn{2}{c}{ Company } & \multicolumn{2}{c}{ Environment } \\
\hline Positive & 73 & 65 & $89 \%$ & 8 & $11 \%$ \\
Negative & 20 & 5 & $25 \%$ & 15 & $75 \%$ \\
\hline Panel B. 2015 & Total & \multicolumn{2}{c}{ Company } & \multicolumn{2}{c}{ E nvironment } \\
\hline Positive & 60 & 48 & $80 \%$ & 12 & $20 \%$ \\
Negative & 18 & 5 & $28 \%$ & 13 & $72 \%$ \\
\hline
\end{tabular}

Moreover, we note from Table 6 that, in relation to the company's environment, the number of positive words used in 2015 is al most similar to the number of negative words used in the sameyear. If the economic conditions were neutral, Petrom's 2015 negative result may be attributed to the company, although the CEO highlights mainly positive results. 
Whether this bias was effective or not may be observed by analysing the context of the company. The same underperformance al so manifested at the group's level. As a result, OMV's CEO Gerhard Roiss was replaced, leading to his subsequent replacement as President of Petrom's supervisory board. However, neither Petrom's CEO nor its CFO were affected by this unfavourable outcome, despite both having held executive positions in the company. At this point it becomes relevant to link with our analysis the following statement made in 2015 by Gerhard Roiss, which illustrates his overall perspective on OMV Petrom:

If we hadn't taken over Petrom, it would have been very difficult to survive in the current dimate (Romania-insider, 2015).

While this quote highlights the real value of the company that was underestimated at the moment when the privatization contract was signed, it also contributes to a better interpretation of our observations. Assuming Petrom's importance for OMV, we consider that an earlier replacement of Mariana Gheorghe would have further affected theimage of Petrom, signalling an overall instability. While the company is highly scrutinized in the Romanian environment, this perspective would have damaged the idea of a successful privatization.

Considering the aforementioned arguments, our results do not support the economic perspective on IM which argues that this opportunistic behaviour may be the result of the managers' intentions to maximize their remuneration (Merkl-Davies \& Brennan, 2011; Yekini et al., 2016) by taking advantage of the information asymmetry that exists between them and the shareholders (Krische, 2005; MerklDavies \& Brennan, 2011; Schrand \& Walther, 2000). While this may be applicable in a diffused ownership, it is not relevant when the ownership is concentrated. Even if the tone of the narratives was positive across the entire period of analysis, the negative results of OMV Petrom triggered the replacement of the president of the supervisory board. In addition, following Fondul Proprietatea's decision to sell part of its stock, the Extraordinary General Meeting of Shareholders approved the secondary listing of OMV Petrom on the London Stock Exchange.

However, our case study suggests that IM may prove its efficiency in order to build, consolidate and eventual ly restore the image of a successful privatization in a highly scrutinized environment. This finding is supported by the positive tone that was kept constant across the entire period of analysis. A nother incentivefor using IM can al so be the need to frame a favourable investment image (Brennan \& Merkl-Davies, 2013) in the context of a secondary public offering. Using a positive tone to express stability even when the results of the company are negative still represents opportunistic behaviour, al beit it may be accepted by the sharehol ders. 


\section{Conclusions}

In this paper we explored the tone used by the managers of OMV Petrom in their letters to sharehol ders in order to identify potential reporting biases. We considered the choice of positive and negative words, the frequency and context in which they were used in the letters to shareholders issued from 2012 to 2015. The results highl ight theopportunistic tendency to present the company's outcomes in a positive light, both in profit and loss periods. This behaviour is consistent with the Pollyanna effect identified in prior literature (Henry, 2008; Rutherford, 2005).

The paper extends the body of work on IM (Allee \& DeAngelis, 2015; Clatworthy \& J ones, 2003, 2006; Feldman etal., 2010; García Osma\& Guillamón-Saorín, 2011; Henry, 2008; Price et al., 2012; Rutherford, 2005; Y ekini et al., 2016; Y uthas et al., 2002), by providing a new perspectivefrom an emerging economy characterized by lack of transparency and low ownership concentration (Albu \& Gîrbină, 2015).

On the one hand, individual and institutional investors may benefit from the results of this study because they "need to adopt a heal thy scepticism” (Clatworthy \& J ones, 2006: 506) in reading corporate narratives and not ,to laud the practice as evidence of increased corporate transparency and accountability" (Cho et al., 2012: 35). On the other hand, this paper will be useful for researchers, since it provides insights from an insufficiently explored research background, i.e. the case of emerging economies in SEE. Finally, accounting policy-makers and professional bodies should try to prevent and detect this opportunistic behaviour because its manifestation contradicts the faithful representation of information (Beattie \& J ones, 2000; Clatworthy \& Jones, 2003, 2006; Guillamón-Saorín \& Martínez-López, 2013), possibly leading to capital misallocations (Merkl-Davies \& Brennan, 2007).

This study is subject to inherent limitations of the methods employed. Handcollecting data may be subject to limitations; however, the subjectivity was mitigated when identifying positive and negative words, due to the use of wordl ists previously developed in the international literature. However, the number of positive and negative keywords was limited to those provided by the two dictionaries used, namely Loughran and McDonald (2011) and Henry (2008). Also, since the paper is a single-company study, results may be difficult to extrapolate in different contexts.

Future research may further investigate other IM strategies, such as causal attributions of performance outcomes. Comparisons could be performed between companies situated in several SEE countries, possibly within the same industry, to assess any country variation in IM practices. Also, an investigation of more listed companies from various industries within the same country may allow inference of conclusions at the country level. Moreover, the potential impact of managers' 
opportunistic behaviour on the decisions made by users of the accounting information can be explored in an experimental setting.

\section{Acknowledgements}

The authors acknowledge the guidance of the editor in chief of JAMIS and the hel pful comments of Sebastian Hoffmann from University of Edinburgh Business School. An earlier version of this paper was presented at the International Conference Accounting and Management Information Systems at the Bucharest University of Economic Studies in 2017 and at the International Conference Financial Reporting and Auditing: Challenges and Opportunities for Accounting Researchers and Educators at the Cracow University of Economics in 2017. This paper was co-financed by The Bucharest University of Economic Studies during Maria-Silvia Săndulescu's $\mathrm{PhD}$ program.

\section{R eferences}

Albu, C.N. \& Albu, N. (2017) „Theroleand current status of IFRS in the completion of national accounting rules - Evidence from Romania", Accounting in Europe, vol.14: 177-186.

Albu, C.N., Albu, N. \& Alexander, D. (2014a) „When gl obal accounting standards meet the local context - Insights from an emerging economy", Critical Perspectives on Accounting, vol. 25, no. 6: 489-510.

Albu, C.N. and Gîrbină, M.M. (2015) „Compliance with corporategovernancecodes in emerging economies. How do Romanian listed companies 'comply-orexplain'?", Corporate Governance: The International J ournal of Business in Society, vol. 15, no. 1: 85-107.

Albu, N. \& Albu, C.N. (2012) „International Financial Reporting Standards in an emerging economy: Lessons from Romania", Australian Accounting Review, vol. 22, no. 4: 341-352.

Albu, N., Albu, C.N., Bunea, Ș., Calu, A.D. \& Gîrbină, M.M. (2011) „A story about IAS/IFRS implementation in Romania", J ournal of Accounting in Emerging Economies, vol. 1, no. 1: 76-100.

Albu, N., Lupu, I. \& Sandu, R. (2014b) „Multinationals as vectors of corporate governance improvement in emerging economies in Eastem Europe: A case study", in Boubaker, S. and Nguyen, D. K. (Eds.), Corporate Governance in Emerging Markets. CSR, Sustainability, Ethics \& Governance, pp. 331-349, Springer-Verlag Berlin Heidel berg.

Allee, K.D. \& DeAngelis, M.D. (2015) „The structure of voluntary disclosure narratives: Evidence from tone dispersion", J ournal of Accounting Research, vol. 53, no. 2: 241-274. 
Baginski, S.P., Hassell, J.M. \& Hillison, W.A. (2000) „Voluntary causal disclosures: Tendencies and capital market reaction", Review of Quantitative Finance and Accounting, vol. 15, no. 4: 371-389.

Beattie, V. \& J ones, M.J . (2000) „Impression management: Thecase of inter-country financial graphs", J ournal of International Accounting, Auditing \& Taxation, vol. 9, no. 2: 159-183.

Berglöf, E. \& Pajuste, A. (2005) „What do firms disclose and why? Enforcing corporate governance and transparency in Central and Eastern Europe", Oxford Review of Economic Policy, vol. 21, no. 2: 178-197.

Brennan, N.M., Guillamón-Saorín, E. \& Pierce, A. (2009) „I mpression management: Developing and illustrating a scheme of anal ysis for narrative discl osures - A methodological note", Accounting, Auditing and Accountability J ournal, vol. 22, no. 5: 789-832.

Brennan, N.M. \& Merkl-Davies, D.M. (2013) „Accounting narratives and impression management", in J ack, L., Davison, J. and Craig, R. (Eds.), The Routledge companion to accounting communication: 109-132, Abingdon: Routledge.

Cho, C.H., Michelon, G. \& Patten, D.M. (2012) „Impression management in sustainability reports: An empirical investigation of the use of graphs", Accounting and the Public Interest, vol. 12: 16-37.

Clatworthy, M.A. \& Jones, M.J. (2001) "The effect of thematic structure on the variability of annual report readability", Accounting, Auditing and Accountability J ournal, vol. 14, no. 3: 311-326.

Clatworthy, M.A. \& Jones, M.J. (2003) „Financial reporting of good news and bad news: Evidence from accounting narratives", Accounting and Business Research, vol. 33, no. 3: 171-185.

Clatworthy, M.A. \& Jones, M.J. (2006) „Differential patterns of textual characteristics and company performance in the chairman's statement", Accounting, Auditing and AccountabilityJ ournal, vol. 19, no. 4: 493-511.

Dainelli, F., Bini, L. \& Giunta, F. (2013) „Signaling strategies in annual reports: Evidence from the disclosure of performance indicators", Advances in Accounting, incorporating Advances in I nternational Accounting, vol. 29, no. 2: 267-277.

Davis, A.K., Ge, W., Matsumoto, D. \& Zhang, J.L. (2015) „The effect of managerspecific optimism on the tone of earnings conference calls", Review of Accounting Studies, vol. 20, no. 2: 639-673.

Davison, J. (2008) „Rhetoric, repetition, reporting and the 'dot.com' era: words, pictures, intangibles", Accounting, Auditing and Accountability J ournal, vol. 21, no. 6: 791-826.

Deaconu, A. \& Cuzdriorean, D.D. (2016) „Accounting and the state in postcommunist Romania", African Journal of Accounting, Auditing and Finance, vol. 5, no. 1: 59-93. 
Dimitriu, S. (2006) „Contractul de privatizare 'Petrom' - sfatul înțelepților' [The privatization contract of 'Petrom'- wise men counsel]", Bursa, 4 December, available on-line at http://www.bursa.ro/energia-contractul-de-privatizarepetrom-sfatul-intelepti lor-2358\&s=companii_afaceri\&articol =2358.html (Accessed 7 November 2017).

Djankov, S., Nikolova, E. \& Zilinsky, J. (2016) „The happiness gap in Eastern Europe", J ournal of Comparative Economics, vol. 44, no. 1: 108-124.

Dobre, A.M. (2010) „Europeanization and new patterns of multi- level governance in Romania", Southeast European and Black Sea Studies, vol. 10, no. 1: 5970.

Eurostat (2016a) „Real GDP growth, 2006-2016”, available on-line at http://ec.europa.eu/eurostat/statistics-explai ned/index.php/File:Real_GDP_ growth, 2006-

2016 (\%25_change_compared_with the previous_year; \%25_per_annum) YB 17.png (Accessed 7 November 2017).

Eurostat (2016b) „Unemployment rate 2005-2016”, available on-line at http://ec.europa.eu/eurostat/statistics-

explained/index.php/File:Unemployment_rate_2005-2016_(\%25)_new.png

(Accessed 7 November 2017).

Eurostat (2017) „HICP - inflation rate”, available on-line at http://ec.europa.eu /eurostat/tgm/table.do?tab=table\&init=1\&language=en \&pcode=tec00118\&p lugin=1 (Accessed 7 November 2017).

Feldman, R., Govindaraj, S., Livnat, J. \& Segal, B. (2010) „Management's tone change, post earnings announcement drift and accruals", Review of Accounting Studies, vol. 15, no. 4: 915-953.

Feleagă, L. \& Feleagă, N. (2016) „Romania. Shifting to IFRS: The case of Romania", in Didier, B. and Praquin, N. (Eds.), IFRS in a Global World: 393404, Cham Springer.

Feleagă, N., Feleagă, L., Dragomir, V.D. \& Bigioi, A.D. (2011) „Corporate governance in emerging economies: The case of Romania", Theoretical \& Applied Economics, vol. 18, no. 9: 5-16.

Fortune (2012) „50 most powerful women in busi ness", 8 October, avai lable on-line at http://archivefortune.com/magazines/fortune/most-powerful-women/2012 /global/ (Accessed 7 November 2017).

Fortune (2013) „The International Power 50: Fortune's Most Powerful Women", 10 October, available on-line at http://fortune.com/2013/10/10/most-powerfulwomen-the-international-power-50/ (Accessed 7 November 2017).

Fortune (2014) „The MostPowerful Women of Europe, the MiddleEastand Africa”, 18 September, available on-line at http://fortunecom/2014/09/18/mostpowerful-women-emea/ (Accessed 7 November 2017).

Garcia Osma, B. \& Guillamón-Saorín, E. (2011) „Corporate governance and impression management in annual results press releases", Accounting, Organizations and Society, vol. 36, no. 4: 187-208. 
Gîrbină, M.M., Albu, N. \& Albu, C.N. (2012) „Corporategovernance disclosures in Romania", in Boubaker, S. and Nguyen, D.K. (Eds.), Board Directors and Corporate Social Responsibility: 122-141, Pal grave Macmillan UK.

Guillamón-Saorín, E. \& Martínez-López, F.J. (2013) "Corporate financial communication and the intemet: Manipulating investor audiences?", Online Information Review, vol. 37, no. 4: 518-537.

Hadro, D., Klimczak, K. \& Pauka, K. (2017) „Impression management in letters to shareholders: Evidence from Poland", Accounting in Europe, vol. 14, no. 3: 305-330.

Henry, E. (2008) „Are investors influenced by how earnings press releases are written?", J ournal of Business Communication, vol. 45, no. 4: 363-407.

Ionașcu, M., Ionașcu, I., Săcărin, M. \& Minu, M. (2014) „IFRS adoption in developing countries: the case of Romania", Accounting and Management Information Systems, vol. 13, no. 2: 311-350.

Krippendorff, K. (2004) Content analysis. An introduction to its methodology, $2^{\text {nd }}$ ed., Thousand Oaks: Sage.

Krische, S.D. (2005) „Investors' evaluations of strategic prior-period benchmark disclosures in earnings announcements", The Accounting Review, vol. 80, no. 1: 243-268.

Leung, S., Parker, L. \& Courtis, J. (2015) „Impression management through mini mal narrative disclosure in annual reports", The British Accounting Review, vol. 47: 275-289.

Loughran, T. \& McDonald, B. (2011) „When is a liability not a liability? Textual analysis, dictionaries, and 10-Ks", J ournal of Finance, vol. 66, no. 1: 35-65.

Loughran, T. \& McDonald, B. (2016) „Textual analysis in accounting and finance: A survey", J ournal of Accounting Research, vol. 54, no. 4: 1187-1230.

Lupu, I. \& Sandu, R. (2017) „Intertextuality in corporate narratives: A discursive analysis of a contested privatization", Accounting Auditing \& Accountability J ournal, vol. 30, no. 3: 534-564.

Macrotrends (2018) „Crude Oil Prices - 70 Y ear Historical Chart”, available on-line at http://www.macrotrends.net/1369/crude-oil-price-history-chart (Accessed 7 November 2017).

Melloni, G. (2015) „Intellectual capital disclosure in integrated reporting: An impression management analysis", J ournal of Intellectual Capital, vol. 16, no. 3: 661-680.

Melloni, G., Stacchezzini, R. \& Lai, A. (2015) "The tone of business model disclosure: An impression management analysis of the integrated reports", J ournal of Management \& Governance, vol. 20, no. 2: 295-320.

Merkl-Davies, D.M. \& Brennan, N.M. (2007) „Discretionary disclosure strategies in corporate narratives: Incremental information or impression management?", J ournal of Accounting Literature, vol. 26, no. 1: 116-194. 
Merkl-Davies, D.M. \& Brennan, N.M. (2011) „A conceptual framework of impression management: New insights from psychology, sociology and critical perspectives", Accounting and Business Research, vol. 41, no. 5: 415-437.

Mueller, D.C. \& Peev, E. (2007) „Corporate governance and investment in Central and Eastern Europe", J ournal of Comparative Economics, vol. 35, no. 2: 414-437.

Musgociu, Ș. (2014) „Petrom a obținut în 2013 un profit record pentru o companie românească" [Petrom reached in 2013 a record profit for a Romanian company], Gândul, 19 February, available on-line at http://www.gandul.info/financiar/petrom-a-obtinut-in-2013-un-profit-recordpentru-o-companie-romaneasca-12111875 (Accessed 7 November 2017).

OMV Petrom (2013) 2013 Annual Report, available on-line at http://www.omvpetromcom/SecurityServlet/secure?cid=1255758867089\&la $\mathrm{ng}=\mathrm{en} \&$ swa_site $=\&$ swa_nav $=\&$ swa_pid $=\&$ swa_lang (Accessed 7 November 2017).

Păun, C., Miclăuș, P. \& Ungureanu, S. (2010) „Initial public offering underpricing effect in case of Eastern European capital markets", Transformations in Business \& Economics, vol. 9, no. 1: 289-305.

Petrescu, R. (2014) „Gerhard Roiss pleacă de la şefia OMV cu doi ani mai devreme şi lasă grupul austriac, acționarul majoritar al Petrom, 'într-o situație extrem de dificilă'[Gerhard Roiss leaves OMV two years earlier and leaves the Austrian group, the major shareholder of Petrom, 'in an extremely difficult situation']", Ziarul Financiar, 16 October, available on-line at http://www.zf.ro/profesii/gerhard-roiss-pleaca-dela-sefia-omv-cu-doi-animai-devreme-si-lasa-grupul-austriac-actionarul-majoritar-al-petrom-intr-osituatie-extrem-de-dificila-13394391 (Accessed 7 November 2017).

Piątek, D., Szarzec, K. \& Pilc, M. (2013) „Economic freedom, democracy and economic growth: A causal investigation in transition countries", PostCommunist Economies, vol. 25, no. 3: 267-288.

Price, S.M., Doran, J.S., Peterson, D.R. \& Bliss, B.A. (2012) „Earnings conference calls and stock returns: The incremental informativeness of textual tone", J ournal of Banking \& Finance, vol. 36: 992-1011.

Riley, T.J. \& Luippold, B.L. (2015) „Managing investors' perception through strategic word choices in financial narratives", The J ournal of Corporate Accounting \& Finance, vol. 26, no. 5: 57-62.

Romania-insider (2015) "How did Romania's Petrom save Austria's OMV?", 18 June, available on-line at https://www.romania-insider.com/how-didromanias-petrom-save-austrias-omv/ (Accessed 7 November 2017).

Romanian Court of Accounts (2014) „Raportul public pe anul 2014” [Public report for the year 2014], available on-line at $h$ ttp://www.curteadeconturi.ro /Publicatii/Raport_public_2014.pdf (Accessed 7 November 2017). 
Rutherford, B.A. (2003) „Obfuscation, textual complexity and the role of regulated narrative accounting disclosure in corporate governance", J ournal of Management \& Governance, vol. 7, no. 2: 187-210.

Rutherford, B.A. (2005) „Genre analysis of corporate annual report narratives: A corpus linguistics-based approach", J ournal of Business Communication, vol. 42, no. 4: 349-378.

Schrand, C.M. \& Walther, B.R. (2000) "Strategic benchmarks in earnings announcements: The selective disclosure of prior-period earnings component", The Accounting Review, vol. 75, no. 2: 151-177.

Tilling, M.V. \& Tilt, C.A. (2010) "The edge of legitimacy. Voluntary social and environmental reporting in Rothmans' 1956-1999 annual reports", Accounting, Auditing \& Accountability J ournal, vol. 23, no. 1: 55-81.

World Bank (2016a) „World Development I ndi cators: Population”, avai lableon-line at https://data.worldbank.org/indicator/SP.POP.TOTL (Accessed 7 November 2017).

World Bank (2016b) „World Development Indicators: GDP”, available on-line at https://data worldbank.org/indicator/NY.GDP.MKTP.KD $\quad$ (Accessed 7 November 2017).

World Economic Forum (2016) "The Global Competitiveness Report 2016-2017", available on-line at http://www3.weforumorg/docs/GCR2016-2017/05 FullReport/TheGlobalCompetitivenessReport2016-2017_FINAL.pdf (Accessed 7 November 2017).

Yekini, L.S., Wisniewski, T.P. \& Millo, Y. (2016) „Market reaction to the positiveness of annual report narratives", The British Accounting Review, vol. 48: 415-430.

Y in, R.K. (2014) Case Study Research: Design and Methods, $5^{\text {th }}$ ed., Thousand Oaks: Sage.

Y uthas, K., Rogers, R. \& Dillard, J.F. (2002) „Communicative action and corporate annual reports", J ournal of Business Ethics, vol. 41, no. 1: 141-157.

Zecchini, S. (2013) Lessons from the Economic Transition: Central and Eastern Europe in the 1990s, New Y ork: Springer Science \& Business Media. 